\title{
CLIMATE CHANGE RISKS, AGRICULTURAL PRODUCTION, AND THE ROLE OF INSURANCE
}

\author{
Vladimir Njegomir, ${ }^{1}$ Radovan Pejanovic ${ }^{2}$, Goran Maksimovic ${ }^{3}$
}

\begin{abstract}
Summary
Climate change in the form of global warming is visible, tangible, measurable and is one of the most significant risks facing the world. During the conceptualization as the objective of the paper, we have determined the analysis of the impact of climate change on agricultural production and the ways of reduction of negative impacts. The most important results of the present work are the analysis of the implications of climate change on agricultural production and food security, adaptation possibilities of agriculture and the role of agriculture insurance. The main conclusions are that climate change negatively affects agricultural production and food security, especially in subtropical areas while there is limited potential for a positive impact of climate change in the northern hemisphere. There are two possible choices for agricultural producers, under the implications of climate change, that are not necessarily mutually exclusive: 1) finding a long term sustainable solution based on the adaptation and 2) obtaining insurance coverage.
\end{abstract}

Keywords: climate change, agriculture, risk, insurance.

JEL: Q01, Q54, G22.

\section{Introduction}

Climate represents the average state of the atmosphere over a town or area in a given time period (Enciklopedija leksikografskog zavoda, 1967). Climate as a time-weighted average represents a mathematical artifact that does not occur in reality (Steht, von Storch, 1999). The climate elements include, for example, the temperature of the air, land and oceans, humidity, precipitation, wind, and the climate factors include the terrain, latitude, distance from the sea, altitude, vegetation and finally a man.

1 Vladimir Njegomir, Ph.D., Associate Professor, Union University, Faculty of Law and Business Studies dr Lazar Vrkatić, Bulevar oslobođenja no. 76, 21000 Novi Sad, Phone: +38164139 3005, E-mail: vnjegomir@eunet.rs

2 Radovan Pejanović, Ph.D., Full Profesor, University of Novi Sad, Agricultural Faculty, Dositeja Obradovica Square no. 8, 21000 Novi Sad, Phone: +381 216350 622, E-mail: pejanovic@uns.ac.rs

3 Maksimović Goran Ph.D., Assistant Professor, University of Prishtina, Faculty of Agriculture, 38219 Leshak, Phone: +381 2888 261, E-mail: goran.maksimovic@pr.ac.rs

EP 2016 (63) 3 (1015-1029) 
Climate affects all aspects of human life, his way of dressing, feelings and behavior, manner and content of the food, costs of heating or cooling. It also determines the diversity of agricultural production, affects the development of tourism, types of plant species. Thus, climate change directly affects all aspects of human life and particularly those elements that are directly determined by climate, such as agriculture.

Climate changes are influenced by minor or major changes in shorter or longer periods of time in the atmosphere, biosphere, lithosphere and hydrosphere. Climate changes are now visible, tangible and measurable, and are one of the most significant risks facing the world. The world is faced with an increase in global average temperature. Since the beginning of the twentieth century until 2014, the average global air temperature rose to $+0.7^{\circ} \mathrm{C}$, whereby this growth has not been continuous. The rapid increase in the average temperature at the global level, in the amount of $+0.18^{\circ} \mathrm{C}$ for the decade, was recorded in the period after 1976. Also, the melting ice is evidenced by NASA data that indicate that the area of ice in the Arctic decreases on average by $9 \%$ per decade. The global average sea levels increased by about 10 to 25 centimeters during the last 100 years.

These consequences of climate changes will directly affect all economic activities and particularly agricultural production. During the conceptualization as the objective of the paper, we have determined the analysis of the impact of climate change on agricultural production and the ways of reduction of negative impacts. In an effort to realize the set goal, in this paper, we analyze the implications of climate change on agricultural production and food security, adaptation measures and the role of agriculture insurance in reducing the negative effects of climate changes.

\section{Methodology and data sources}

Our research is focused on the analysis of the climate changes implications on sustainability of agricultural production and measures that agricultural producers can use to absorb the negative consequences. We use statistical methods in research, with the aim of the data processing and comparation method of theoretical basics and empirical solutions of different riks measures applications. Primarily, we folow the movements of indices and trends of climate changes and their impacts on agricultural production and food security. We compare foreign empirical evidence and experiences in agricultural production risk managment and give proposals of their applications in Serbia.

Using combined data we explore the issue of food security and adaptation measures and insurance as the most important measures that agricultural producers can use in managing production risks. After comparing various available forms of prevention and financing of consequences of climate changes with foreign empirial evidence we give proposals for improvement in terms of efficiency of applied risk managment practices in Serbia.

Data are gathered from verious trustfull sources. We use sources of various leading scientists in the field of agricultural economics, risk management and insurance. We base our conclusions on data from Intergovernmental Panel on Climate Change, European Commission, Food and Agricultural Organization of the United Nations, Commodity Exchange in Novi Sad and World Bank. 


\section{Climate changes implications on agricultural production}

The impact of climate change, which are evident in the increase of atmospheric and sea temperature, melting of ice and rising sea levels, on the agricultural production is not the same in all areas of the world nor is it easy predictable. However, there are consequences that can be associated with higher temperatures. These consequences can be divided into potentially positive and potentially negative to agricultural production and insurers of production risks of agricultural production.

Positive effects of climate changes in agricultural production may include (Heintz, 2008):

- Rapid expansion of thermophilic plants, or plants that require a warmer environment for the normal development in the northern areas;

- Farmers will be able to grow crops with longer vegetation stages, which will result in increased yields;

- The extended growth phase will extend the period of grazing pastures;

- Higher levels of carbon dioxide support photosynthesis;

- Increased precipitation in some areas will increase yields.

The negative consequences of climate changes in agricultural production may include (Heintz, 2008):

- Extended periods with temperatures above $35^{\circ} \mathrm{C}$ would cause heat stress in flowering plants, which will reduce yields in subtropical areas to $70 \%$;

- Higher temperatures in northern areas will increase evaporation, significantly disrupting the water balance in the soil and in plants;

- Higher rates of evaporation in tropical and subtropical areas will dry land and will be the cause of the salinization and reduction of arable land;

- Higher temperatures will accelerate the process of flowering of fruit trees, which will increase the risk of the impact of late spring frosts to flowers;

- The higher temperatures of the seas and oceans will have direct influence on aquaculture where the most dangerous effects will be the spread of flowering of seaweed and jellyfish as well as the warming of streams intended for aquaculture. Water contains less of oxygen when heated, and can cause a negative effect on fish and other organisms;

- Patterns of animals' infections can be changed and the increase in the density of organisms and geographical coverage is possible;

- Decreased rainfall in some areas will reduce yields;

- Increased precipitation in some areas will increase the humidity and reduce yields;

- Increasing temperature leads to less snowfall, which will cause lower spring moisture that plants need in the spring. There will be an increase in forest fires in North America; 
- Areas where climate changes will cause a complete cessation of rainfall, agricultural production will not be possible (for example, the agricultural production in Australia will move from the southeast to the northwest part of the country).

The latest in a series of reports of the Intergovernmental Panel on Climate Change (IPCC, 2014) confirms the key findings of the previous report concerning the evolution of the climate as well as the key physical effects, such as effects on the land and oceans, temperature change, sea level rise and increasing ocean acidity. All these changes caused by climate changes have a negative impact on all aspects of agricultural production. This report indicates that the impacts of climate changes occur in a series of physical changes and indirect impacts on the systems and then on humans (see Figure 1).

Figure 1. Chain impacts of climate change on agricultural production and food security

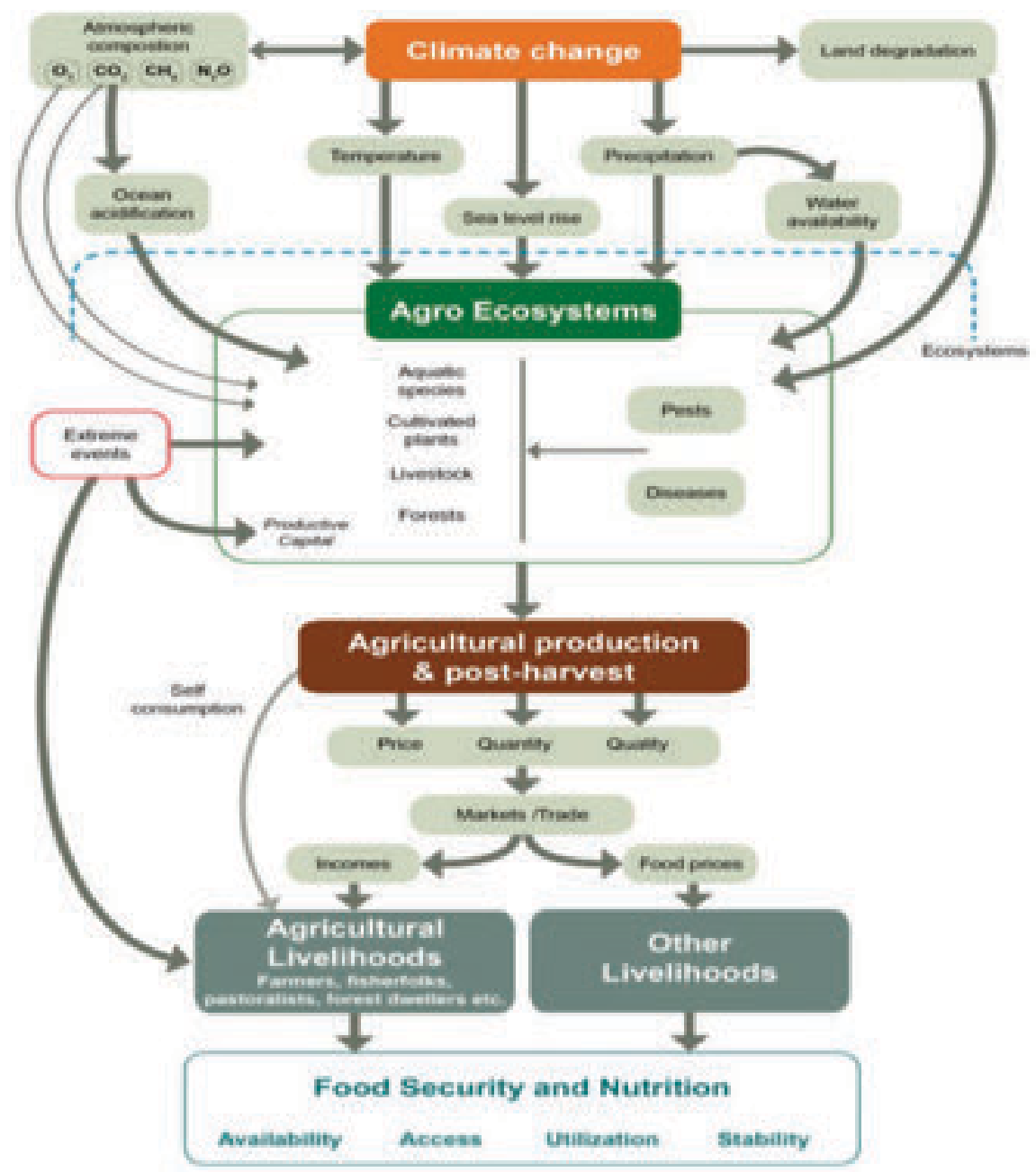

Source: FAO (2016a). 
Global climate change, in addition to the direct impact of the increase in catastrophic events, such as hurricanes and winter storms, has numerous other effects, such as impacts to the availability of food, habitation, human health, ecosystems and water resources.

Springs occur earlier, which has an impact on the Earth's biological systems, including changes such as bird migration and egg-laying and changes in the types of plants and animals. In the Alps, for example, it is observed that certain plant species migrate upward by one to four meters per decade and some species of plants that were previously found only on mountain tops are completely extinct.

Thanks to the increase in air temperature there are changes in the diversity of animal species, in particular insects, because it is found that butterflies, dragonflies, moths, beetles and other insects live in large areas, both in terms of latitude and altitude, at which they were not be able to survive before due to the cold. Increased water temperatures, combined with changes in the surface of the ice cover, salinity and oxygen levels, influence the change in the diversity of both marine and freshwater flora and fauna. Projected changes in average annual temperatures and average rainfall in Europe until the end of the XXI century are presented in figures 2 and 3.

Figure 2. Projected changes in average annual temperature by the end of the twenty-first century

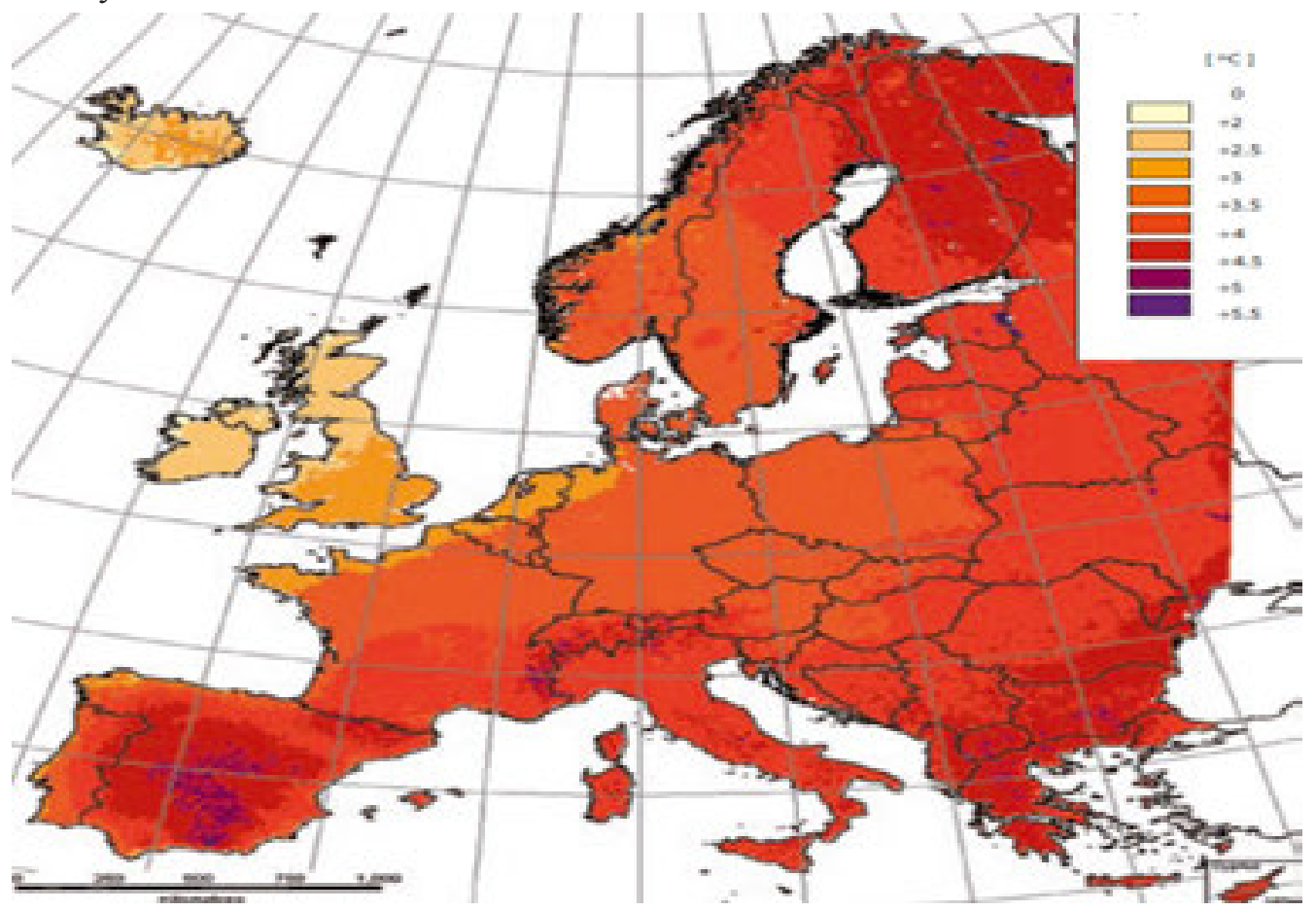

Source: EC (2008). 
Figure 3. Projected changes in average annual precipitation by the end of the twenty-first century

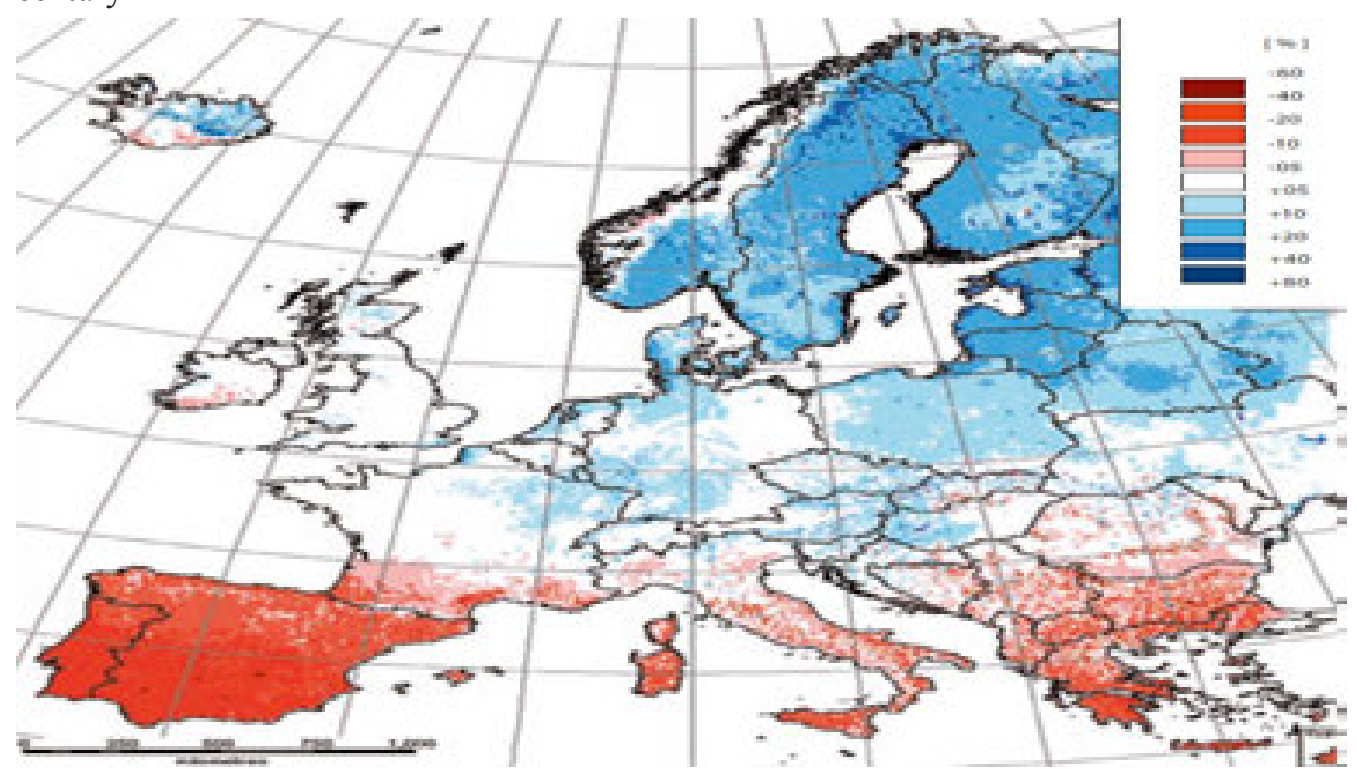

Source: EC (2008).

Figures showing projected changes in average annual temperatures and annual precipitation clearly indicate that changes in agricultural production also affect Europe. Some of the changes in the agricultural production are already felt.

A warmer and drier years will contribute to a greater likelihood of heat waves and droughts on one the hand, and floods on the other. This is indicated by a study of Bernard Lehner and his colleagues at the University of Kassel in Germany, which was published in the scientific journal "Climatic Change" (Lehner et al., 2006). This study deals with the risks posed by floods and droughts in Europe. An integrated analysis of possible impacts of climate changes on the future realization of floods and droughts on the continent indicates that in northern and north-eastern parts of Europe will be increased likelihood of floods in the future while in the southern and southeastern parts of Europe will be increased probability of droughts, whereby the extreme events, floods and droughts will occur with a higher likelihood (estimates are that they will occur every 10 to 50 years by 2070 , and their current frequency is on average every 100 years). These developments will result in adverse events such as forest fires, as well as damages in sectors such as agriculture, domestic freight forwarding and supply.

Estimates are that at lower latitudes there will be the decline in yields of agricultural production, which can lead to increased risk of hunger in these areas (EC, 2008). In higher latitudes, such as areas further north in the northern hemisphere, there will be a modest increase in the yield of agricultural production if the temperature does not rise by more than $3^{\circ} \mathrm{C}$, but if the rise would be greater even in these areas will be a decline in the results of agricultural production (EC, 2008). 
Assumed escalating of problems with droughts and water scarcity will cause the reduction of arable land and an increase in desert areas. There are also forecasts that indicate that the entire Mediterranean basin will be exposed to severe droughts. Very high temperatures can induce structural changes caused by subsidence of soil in areas where the soil structure is dominated by clay, a phenomenon that is already manifested in the UK.

\section{Food security under conditions of realization of climate change risks}

Food security, and its sufficient availability of nutrition of the population is the key reason for the existence of agricultural production since it firstly occurred. With the increasing population needs to increase agricultural production are continuing. The assumption is that by 2050 , global agricultural output will have to increase by $60 \%$ compared to today's levels. Namely, in order to meet the food needs of the projected population growth and food consumption per capita, historically manifested continuity of growth in agricultural production will have to continue in order to ensure the doubling of current production (Tubiello, Jean-Francois, Howden, 2007).

The historical trend of growth in agricultural production occurs from the fifties of the twentieth century from when significant investment in the productivity of agricultural production has been made. The whole process is called Green Revolution, which is considered to be resulted with today's levels of over $170 \%$ more grain to only $8 \%$ increase of cultivated land, compared to more than 50 years ago. Such an increase in production volume provided that the current volume of production of cereals provides food security at a level of $1 \mathrm{~kg}$ per person per day (Burke, Lobell, 2010). These data refer to the average in the world. However, there are significant regional differences, and it is believed that globally more than one billion people are actually starving. This is due to faster population growth than is the growth in the volume of agricultural production. Viewed regionally in the world, only in Africa a real drop in cereal production per capita has been noticed. The reason is the fast growth of population relative to cereal production.

With the adoption of sustainable development goals, the world is dedicated to hunger elimination, security and safety of food and nutrition improvement in 2030. However, the big problem is climate changes. It is believed that in the future it can only be expected decline in the volume of agricultural production in the world, especially when viewed in correlation with the increasing population. Although there will be a slower population growth, climate change has already begun to undermine the livelihood and food security of the most vulnerable populations. Ensuring food security and good nutrition status under conditions of climate changes is a serious challenge that humankind faces already (FAO, 2016).

The only way to avoid the effects of climate change on the reduction in the volume of agricultural production and the volume of arable land is the international exchange. An additional issue that arises is the question of access to food, that is the questions of whether the countries in which the food security is compromised will be able to share food. The answer to this question is linked to the movement of prices of agricultural products and food on the global level. Growth in global food prices has been particularly evident since 2005 (see Figure 4) when, after a catastrophic drought in the US global food prices reached a 
historic record level. Soaring food prices in the period from 2005 to 2013 was 74\%. In such circumstances, it is evident that access to food will be reduced in poorer countries, especially with more pronounced effects of climate changes, which will further contribute to the growth of food prices, as shown by 2012.

Figure 4. Indices of food prices in the world in the period 1961-2015 (2002-2004=100)

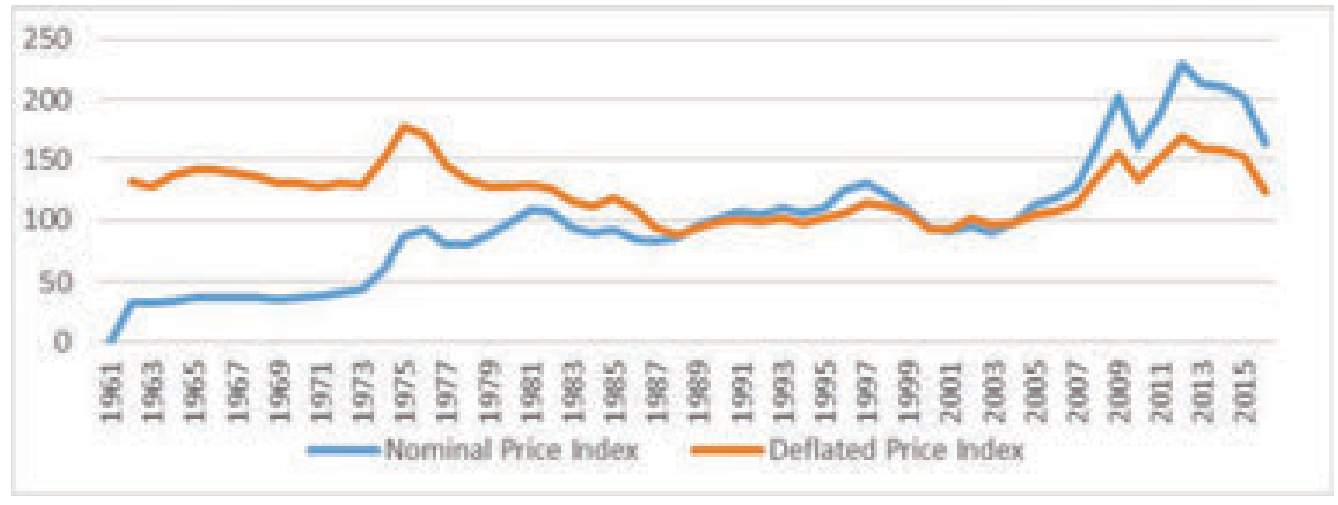

Source: FAO (2016b).

The international food price index of the Food and Agriculture Organization (FAO) is presented in the Figure 4. This index is a measure of the monthly changes in international prices of the food basket. This basket consists of the average price index for the five groups of food products, with an average, weighted share of each of the five groups in total exports in 2002-2004. Similar trends of sharp price movements are manifested in Serbia at the Commodity Exchange in Novi Sad (see Figure 5).

Figure 5. The index of market prices of primary agricultural products on the Commodity Exchange in Novi Sad (PRODEX)

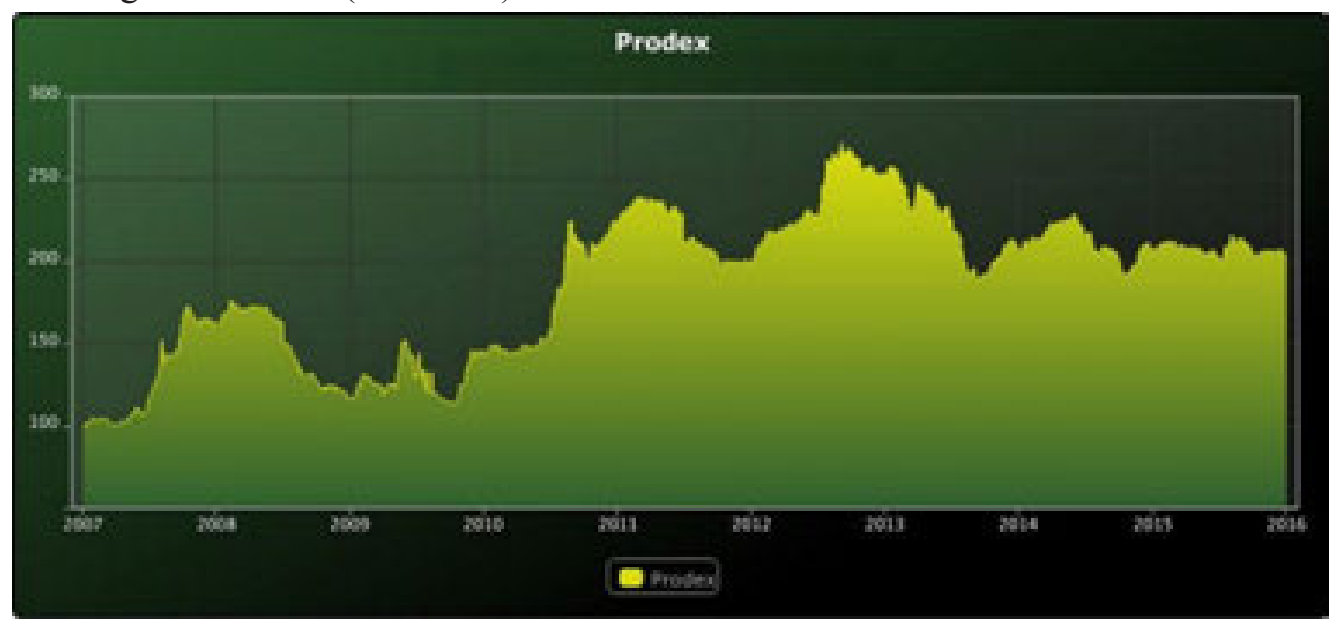

Source: PRODEX (2016). 
Figure 5 shows similar price movements or the movements observed, but all that movement is at higher price levels, especially in the period after 2010, when there was a sudden increase in the prices of agricultural products.

\section{Adaptation of agriculture to climate changes}

Climate changes are real and are a cause of concern for sustainable economic development, and in particular sustainable development of agriculture. Finding adaptation solutions is critical in the years to come, particularly in agriculture. The main task of adaptation measures is the reduction of the vulnerability of agricultural production to the catastrophic damages caused by climate changes and strengthening of the capacity of rural areas for recovering of their economy and environment.

Estimates of the International Organization for Food and Agriculture (FAO) are that 11\% of arable land in developing countries will be lost by 2085 due to climate changes, which will reduce the production of cereals in more than 65 countries (McClean et al., 2005). If we consider Africa in particular, estimates are that $25 \%$ to $42 \%$ of the habitat will be lost, which will jeopardize agricultural production and the reduction in crops for food and medicinal purposes. Thus, agricultural production is relatively under the greatest negative impact of climate changes, which is especially highlighted in the least developed countries. Unlike undeveloped countries, the developed countries of the northern hemisphere to some extent will be able to take advantage of the positive effects of global warming. The problem in developing countries, and especially in undeveloped countries, is the fact that in these countries adequate institutions and infrastructure for dealing with climate changes does not exist, despite the fact that agricultural production has a very important role in their national economies.

Adaptation of agricultural production to climate changes does not require a completely innovating of agricultural practices. It requires the adjustment of good agricultural practices to changes in environmental conditions. Adaptation refers to policies, practices and projects with the aim for reduction of negative consequences and/or exploitation of the opportunities that are associated with climate changes, including climate variability and extremes (EEA, 2016). Another approach to the interpretation of the term "adaptation" involves the activities of policies, processes and capital adjustments in order to respond to the presence of climate changes, as well as the changes in social, institutional and technical structures and features that affect capacity for the recognition and realization of these activities. (Adger et al., 2007).

There are a wide variety of adaptive measures of agricultural production to climate changes. These measures include various options, from technology to management, such as production practices, and policy, such as adaptation action plans (Howden et al., 2007). Measures that can be applied for the adaptation vary from those that creates smaller or larger changes in the existing agricultural systems. Implementation of the measures that have a marginal impact on the existing agricultural systems can have significant benefits under conditions of moderate climate changes. However, there are limits of the effectiveness of such changes in the conditions of serious climate changes. Therefore, the systemic changes are necessary 
in the allocation of the resources, such as targeted diversification of production systems and livelihood.

Agricultural producers apply a series of measures aimed at adaptation to climate changes. These measures include crop rotation in order to make best use of available water resources, adjusting sowing dates according to temperature and rainfall patterns, use different types of crops that are better adapted to new weather conditions that can include extreme temperatures and droughts, planting of hedges with the aim of protection from wind and evaporation. Providing better information on climate risks and adaptation options, advisory services and training of farmers are key adaptive measures in agriculture.

Adaptation strategies for the agricultural production exposed to climate changes are already prepared or developed in various countries of the European Union. The focus of these adaptation strategies is mainly the prevention of impacts of weather extremes that are considered imminent danger, such as floods.

As climate changes intensify, farmers may need to use other types or new crops. Some adaptation measures imposed by climate changes will be costly due to heavy investments in new equipment and infrastructure, such as building or improving irrigation systems or adapting ventilation in barns. Agricultural producers cannot themselves bear the burden of application of adaptation measures. Public policy should provide adequate support to allow farmers to adapt structures of agricultural holdings and production methods and to continue providing services to rural surroundings.

\section{The role of the agricultural insurance}

Agricultural production is threatened by a number of risks which are managed in different ways (Pejanović, Njegomir, 2011). Among the methods available for production risks management the most important role has insurance. Insurance improves agricultural production by making farmers' entrepreneurial activities more stable and certain. Insurance reduces the uncertainty of farmers and the need for creation of individual savings accounts or funds, given that the need for cash reserves is reduced (Raulston et al., 2010) By releasing the need for accumulation of surplus funds that can be profitably engaged, insurance additionally supports agricultural development (Njegomir, Pejanović 2011). In addition to indirect economic protection from the destructive effects of natural forces and human activities, insurance represents a form of security pledge (collateral) that allows agricultural producers easier access to capital through loans at lower costs. The importance of agriculture insurance is evidenced through the exclusion of state subsidies for the payment of insurance premiums from the Free Trade Agreement signed within the World Trade Organization in 1994, provided that the insurance provides financial compensation for the climate and natural disasters (Baez, Wong, 2007).

Despite the great importance that insurance has, various studies have shown conflicting results regarding the factors that have a positive impact on agricultural producers to conclude insurance contracts. For example, Velandia et al. (2009) found that the conclusion of insurance contracts is positively affected by the level of business risks while it is negatively influenced with land ownership, income achieved outside agriculture and education. However, 
Sherricketal (2004) found that farmers are more willing to conclude insurance if their perceived risk for the realization of yields is greater and if they are engaged in production on farms that are larger, older and that are not leased. Also, Enjolras and Sentis (2008) analyzing the agricultural insurance in France found that the size and financial strength of farmers, diversified production and catastrophic climatic events have a positive impact on farmers' decision on the conclusion of insurance.

Historically, agricultural insurance has evolved from hail insurance, when during the last century, farmers have organized in societies for risk sharing, in order to protect their crops from the risk of fire. Over time, the scope of coverage has widened in terms of risks' covered, but also in terms of types of agricultural insurance. Global agriculture insurance premium has reached 18.5 billion dollars in 2008, of which the largest part (about 62\%) came from North America, 18\% from Asia, 16\% from Europe and the rest from Latin America, Africa and Australia. Total realized agriculture insurance premium in emerging markets in 2007 was less than $20 \%$ of global premium (Baez, Wong, 2007).

The basic division of agricultural insurance is the division on crop insurance and livestock insurance. Crop insurance provides coverage for all types of crops, fruits, flowers and vegetables, and livestock insurance covers losses that may arise due to the death or unplanned destruction, illness or accidental injury of horses, pigs, sheep, bulls, cows, calves and goats and other domestic animals, and in some cases some wild animals may be included. Crop insurance is the most widespread type of agriculture insurance, which accounted for about $90 \%$ of the total agriculture premium in 2008 (Iturrioz, 2009). Insurance types that are common in agriculture insurance include: 1) traditional insurance, based on the compensation of the actual losses caused by the insured risk or all risks, 2) yield insurance and 3) insurance based on the application of the indices (see Table 1). 
Table 1. Types of agricultural insurance

\begin{tabular}{|c|c|c|}
\hline $\begin{array}{l}\text { Type of Agricultural } \\
\text { Insurance Product }\end{array}$ & Payouts & Availability \\
\hline \multicolumn{3}{|c|}{$\begin{array}{l}\text { a) Indemnity Based Agricultural Insurance } \\
\text { (insurance payouts based on the actual loss at the insured unit level) }\end{array}$} \\
\hline 1. Named Peril & Percentage of Damage & Widespread \\
\hline 2. Multiple Peril & Yield Loss & Widespread \\
\hline \multicolumn{3}{|c|}{$\begin{array}{l}\text { b) Index based Agricultural Insurance } \\
\text { (insurance payouts based on an index measurement) }\end{array}$} \\
\hline 3. Area-Yield Index & Area-yield Loss & USA, India, and Brazil \\
\hline 4. Crop Weather Index Insurance & Weather Index payout scale & $\begin{array}{l}\text { India, México, Malawi, } \\
\text { Canada, USA }\end{array}$ \\
\hline 5.NDVI' Index Insurance & NDVI Index payout scale & Mexico, Spain, Canada \\
\hline $\begin{array}{l}\text { 6. Livestock Mortality Index } \\
\text { Insurance }\end{array}$ & $\begin{array}{l}\text { Livestock mortality index } \\
\text { payout scale }\end{array}$ & Mongolia \\
\hline $\begin{array}{l}\text { 7. Forestry Fire Index } \\
\text { Insurance }\end{array}$ & $\begin{array}{l}\text { Ignition focus/ burnt area } \\
\text { payout scale }\end{array}$ & Canada, USA \\
\hline \multicolumn{3}{|c|}{$\begin{array}{l}\text { c) Crop Revenue Insurance } \\
\text { (insurance payouts based on yield measurement and crop prices) }\end{array}$} \\
\hline 6. Crop Revenue Insurance (CRI) & Yield and Price Loss & Limited to USA \\
\hline
\end{tabular}

Source: World Bank (2009).

\section{Conclusion}

By conducting analyses that have been presented in the work, we have come to the conclusion that the impact of climate changes on agricultural production and food security is proven, visible and greatly limiting for the agricultural production. In fact, if current trends of climate changes continue, agricultural production will be strongly negatively impacted. Positive effects can be expected in the northern hemisphere, but only on condition that there is no accelerated pace of climate changes.

Agricultural producers in dealing with the effects of climate changes have at their disposal two key mechanisms: 1) finding a long term sustainable solution based on the adaptation and 2) obtaining insurance. The implementation of these mechanisms, especially with regard to the implementation of adaptation measures, can be very expensive. Public policy should provide adequate support to allow farmers to adapt agricultural production to amended climate conditions. 


\section{Literature}

1. Adger, W.N. (2007): in Climate Change 2007: Impacts, Adaptation and Vulnerability, eds Parry ML , Canziani OF , Palutikof JP , van der Linden PJ and Hanson CE, Cambridge University Press, Cambridge, UK, pp. 717-743.

2. Baez, M.S., Wong, S. (2007): Insurance in emerging markets: sound development; greenfield for agricultural insurance. Sigma No 1/2007, Swiss Re, Zurich.

3. Burke, M., Lobell, D. (2010): Climate Effects on Food Security: An Overview in Lobell, D. and Burke, M. (eds): Climate Change and Food Security: Adapting Agriculture to a Warmer World, Springer, New York.

4. EC (2008): Climate Change: The Challenges for Agriculture. Fact Sheet, DirectorateGeneral for Agriculture and Rural Development, European Commission, Brussels.

5. EEA (2016): Technical report $n^{\circ} 7 / 2005$ and glossary of the IPCC Third Assessment Report, http:/www.ipcc.ch/ipccreports/tar/wg1/index.php?idp=518 (accessed 03.02.2016.)

6. Enciklopedija leksikografskog zavoda. (1967): Jugoslovenski leksikografski zavod, Zagreb.

7. Enjolras, G., Sentis, P. (2008): The Main Determinants of Insurance Purchase: An Empirical Study on Crop Insurance Policies in France. Paper presented at the 12th EAAE Congress "People, Food and Environments: Global Trends and European Strategies", Gent (Belgium), 26-29 August.

8. FAO (2016a): Climate change and food security: risks and responses. Food and Agricultural Organization of the United Nations, Rome.

9. FAO (2016b): Food Price Index, http://www.fao.org/worldfoodsituation/ foodpricesindex/en (accessed 15.01.2016.)

10. Heintz, T. (2008): Winds of Change for Agricultural Risk. Catastrophe Risk Management, Guy Carpenter, December, 2008.

11. Howden, S.M., Soussana, J.F., Tubiello, F.N., Chettri, N., Dunlop, M., Meinke, H. (2007): Adapting agriculture to climate change. Proceedings of the National Academy of Sciences of the United States of America, Vol. 104, No. 50, pp. 19691-19696.

12. IPCC (2014): Climate change 2014: synthesis report. Contribution of Working Groups I, II and III to the Fifth Assessment Report of the Intergovernmental Panel on Climate Change. Core Writing Team, R.K. Pachauri \& L.A. Meyer, eds. Geneva, Switzerland.

13. Iturrioz, R. (2009): Agricultural Insurance. Primer Series on Insurance, The World Bank, Washington, DC.

14. Lehner, B., Doll, P., Alcamo, J., Henrichs, T., Kaspar, F. (2006): Estimating the impact of global change on flood and drought risks in Europe: a continental, integrated analysis. Climatic Change, Vol. 75, No. 3, pp. 273-299

15. McClean, C.J. Lovett, J.C., Kuper, W., Hannah, L., Sommer, J.H., Barthlott, W., Taplin, J.R. (2005): African Plant Diversity and Climate Change, Annals of the Missouri 
Botanical Garden, Vol. 92, No. 2, pp. 139-152.

16. Njegomir, V., Pejanović, R. (2011): Importance and current issues in agricultural insurance in Serbia. Contemporary Agriculture, Vol. 60, No. 1-2, pp. 38-45

17. Pejanović, R.., Njegomir, V. (2011): Problemi upravljanja rizicima u poljoprivredi. Ekonomika poljoprivrede, Vol. 58, No. 1, pp. 91-103.

18. PRODEX (2016): Produktna berza u Novom Sadu, http://www.proberza.co.rs/graph/ prodex/

19. Raulston, J.M., Richardson, J.W., Outlaw, J.L., Knapek, G.M. (2010): Does Crop Insurance Reduce the Need for Cash Reserves in Savings Accounts? Paper presented at the SAEA Annual Meeting, Orlando, FL, February 6-9.

20. Sherrick, B.J., Barry, P.J., Ellinger, P.N., Schnitkey, G.D. (2004): Factors Influencing Farmers 'Crop Insurance Decisions. American Journal of Agricultural Economics, Vol. 86, No. 1, pp. 103-114.

21. Steht, N., von Storch, H. (1999): Klima, Wetter, Mensch. Verlag CHBeck, Munich.

22. Tubiello, F.N., Jean-Francois, S., Howden, S.M. (2007): Crop and pasture response to climate change. Proceedings of the National Academy of Sciences of the United States of America(PNAS), Vol. 104, No. 50, pp. 19686-19690.

23. Velandia, M., Rejesus, R.M., Knight, T.O., Sherrick, B.J. (2009): Factors Affecting Farmers' Utilization of Agricultural Risk Management Tools: The Case of Crop Insurance, Forward Contracting, and Spreading Sales. Journal of Agricultural and Applied Economics, Vol. 41, No. 1, pp. 107-123

24. World Bank (2009): Insurance for the Poor Program, Public Intervention for Agricultural Insurance, World Bank, New York. 


\title{
RIZICI OD KLIMATSKIH PROMENA, POLJOPRIVREDNA PROIZVODNJA I ULOGA OSIGURANJA
}

\author{
Vladimir Njegomir ${ }^{4}$, Radovan Pejanović ${ }^{5}$, Goran Maksimović ${ }^{6}$
}

Rezime

Promena klime u vidu globalnog zagrevanja je vidljiva, opipljiva i merljiva i predstavlja jedan on najznačajnijih rizika sa kojima se svet suočava. Prilikom konceptualizacije kao cilj rada odredili smo analizu uticaja klimatskih promena na poljoprivrednu proizvodnju $i$ načina za redukciju negativnih uticaja. Najvažnije rezultate u radu predstavljaju analize implikacija klimatskih promena na poljoprivrednu proizvodnju i sigurnost hrane, adaptacione mogućnosti poljoprivrede i ulogu osiguranja poljoprivrede. Osnovni zaključci su da klimatske promene utiču značajno negativno na poljoprivrednu proizvodnju i sigurnost hrane, posebno u suptropskim oblastima dok u severnoj hemisferi postoji potencijal za pozitivan uticaj klimatskih promena. Postoje dva ključna moguća izbora za poljoprivredne proizvođače u uslovima implikacija klimatskih promena koji ne moraju biti međusobno isključivi: 1) pronalaženje dugoročno održivog rešenja na bazi adaptacije i 2) pribavljanje osiguravajućeg pokrića.

Ključne reči: klimatske promene, poljoprivreda, rizik, osiguranje.

4 Vanredni profesor, dr Vladimir Njegomir, Univerzitet Union, Fakultet za pravne i poslovne studije dr Lazar Vrkatić, Bulevar oslobođenja br. 76, 21000 Novi Sad, Telefon: +381 64139 3005, E-mail: vnjegomir@eunet.rs

5 Redovni profesor, dr Radovan Pejanović, Univerzitet u Novom Sadu, Poljoprivredni fakultet, Trg Dositeja Obradovica br. 8, 21000 Novi Sad, Telefon: +381 216350622 E-mail: pejanovic@uns.ac.rs

6 Docent, dr Maksimović Goran, Univerzitet u Prištini, Poljoprivredni fakultet, 38219 Lešak, Telefon: +381 2888 261, E-mail: goran.maksimovic@pr.ac.rs

EP 2016 (63) 3 (1015-1029) 